\title{
Thermochemical surface engineering of steels
}

\author{
Mittemeijer, Eric J. ; Somers, Marcel A. J.
}

Publication date:

2015

Document Version

Publisher's PDF, also known as Version of record

Link back to DTU Orbit

\section{Citation (APA):}

Mittemeijer, E. J., \& Somers, M. A. J. (Eds.) (2015). Thermochemical surface engineering of steels. Woodhead Publishing. Woodhead Publishing Series in Metals and Surface Engineering No. 62

\section{General rights}

Copyright and moral rights for the publications made accessible in the public portal are retained by the authors and/or other copyright owners and it is a condition of accessing publications that users recognise and abide by the legal requirements associated with these rights.

- Users may download and print one copy of any publication from the public portal for the purpose of private study or research.

- You may not further distribute the material or use it for any profit-making activity or commercial gain

- You may freely distribute the URL identifying the publication in the public portal

If you believe that this document breaches copyright please contact us providing details, and we will remove access to the work immediately and investigate your claim 

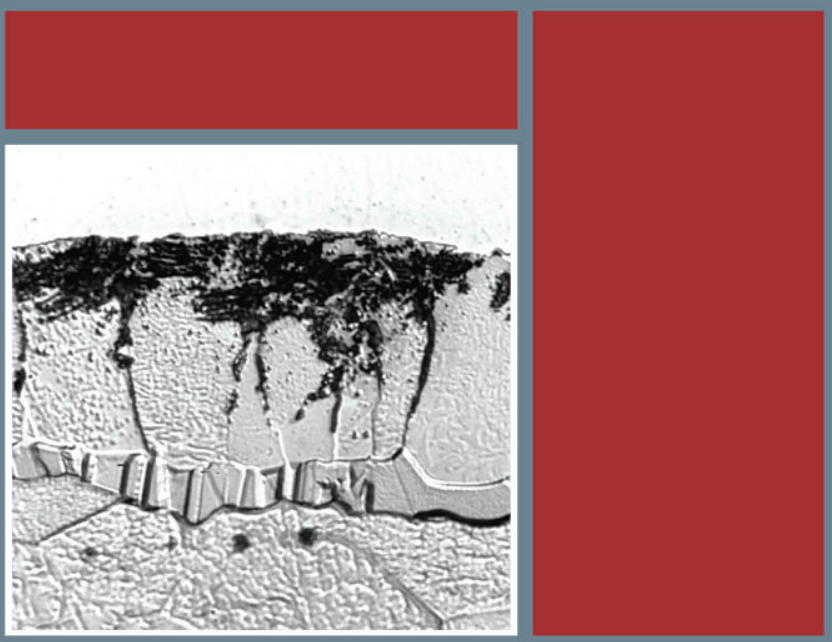

\section{Thermochemical Surface Engineering of Steels}

Edited by Eric J. Mittemeijer and Marcel A. J. Somers 
Thermochemical Surface Engineering of Steels 


\section{Related titles}

Handbook of smart coatings for materials protection (ISBN 978-0-85709-680-7)

Rare earth-based corrosion inhibitors

(ISBN 978-0-85709-347-9)

Underground pipeline corrosion

(ISBN 978-0-85709-509-1) 
Woodhead Publishing Series in Metals and Surface Engineering: Number 62

\section{Thermochemical Surface Engineering of Steels}

Edited by

\section{Eric J. Mittemeijer and Marcel A. J. Somers}

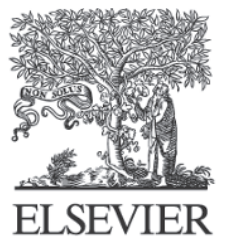


Woodhead Publishing is an imprint of Elsevier

80 High Street, Sawston, Cambridge, CB22 3HJ, UK

225 Wyman Street, Waltham, MA 02451, USA

Langford Lane, Kidlington, OX5 1GB, UK

Copyright (C) 2015 Elsevier Ltd. All rights reserved.

No part of this publication may be reproduced, stored in a retrieval system or transmitted in any form or by any means electronic, mechanical, photocopying, recording or otherwise without the prior written permission of the publisher.

Permissions may be sought directly from Elsevier's Science \& Technology Rights Department in Oxford, UK: phone (+44) (0) 1865 843830; fax (+44) (0) 1865 853333; email: permissions@elsevier.com. Alternatively you can submit your request online by visiting the Elsevier website at http://elsevier.com/locate/permissions, and selecting Obtaining permission to use Elsevier material.

\section{Notice}

No responsibility is assumed by the publisher for any injury and/or damage to persons or property as a matter of products liability, negligence or otherwise, or from any use or operation of any methods, products, instructions or ideas contained in the material herein. Because of rapid advances in the medical sciences, in particular, independent verification of diagnoses and drug dosages should be made.

\section{British Library Cataloguing-in-Publication Data}

A catalogue record for this book is available from the British Library

Library of Congress Control Number: 2014943554

ISBN 978-0-85709-592-3 (print)

ISBN 978-0-85709-652-4 (online)

For information on all Woodhead Publishing publications

visit our website at http://store.elsevier.com/

Typeset by Replika Press Pvt Ltd, India

Printed and bound in the United Kingdom 


\section{Contents}

About the editors xiii

List of contributors $\quad$ Xv

Woodhead Publishing Series in Metals and Surface Engineering xvii

Introduction $\quad$ xxi

Part One Fundamentals $\quad 1$

1 Thermodynamics and kinetics of gas and gas-solid reactions 3

J. T. Slycke, E. J. Mittemeijer, M. A. J. Somers

1.1 Introduction $\quad \mathbf{3}$

1.2 Equilibria for gas-exchange reactions $\quad 6$

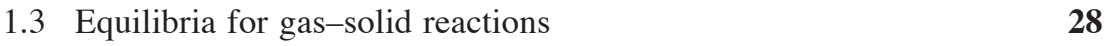

1.4 Kinetics of gas-exchange reactions $\quad \mathbf{5 1}$

$\begin{array}{lll}1.5 & \text { Kinetics of gas-solid reactions } & \mathbf{7 5}\end{array}$

1.6 Phase stabilities in the Fe-N, Fe-C and Fe-C-N systems 96 $\begin{array}{lr}\text { References } & 109\end{array}$

2 Kinetics of thermochemical surface treatments $\mathbf{1 1 3}$

E. J. Mittemeijer, M. A. J. Somers

$\begin{array}{lll}2.1 & \text { Introduction } & \mathbf{1 1 3}\end{array}$

2.2 Development of an interstitial solid solution $\mathbf{1 1 3}$

2.3 Precipitation of second phase particles in a supersaturated matrix 124

$\begin{array}{lll}2.4 & \text { Product-layer growth at the surface } & \mathbf{1 2 8}\end{array}$

$\begin{array}{ll}2.5 \text { Conclusion } & 138\end{array}$

References 139

3 Process technologies for thermochemical surface engineering $\quad 141$

K-M. Winter, J. Kalucki, D. Koshel

$\begin{array}{lll}3.1 & \text { Introduction } & \mathbf{1 4 1}\end{array}$

$\begin{array}{ll}3.2 & \begin{array}{l}\text { Different ways of achieving a hardened wear-resistant } \\ \text { surface }\end{array}\end{array}$

$\begin{array}{llr}3.3 & \text { Furnaces } & 144\end{array}$

$\begin{array}{lll}3.4 & \text { Gaseous carburising } & \mathbf{1 5 8}\end{array}$

$\begin{array}{lll}3.5 & \text { Gaseous carbonitriding } & \mathbf{1 6 6}\end{array}$

$\begin{array}{lll}3.6 & \text { Gaseous nitriding and nitrocarburising } & \mathbf{1 7 0}\end{array}$

3.7 Variants of gaseous nitriding and nitrocarburising $\mathbf{1 7 6}$

$\begin{array}{lll}3.8 & \text { Gaseous boriding } & \mathbf{1 7 9}\end{array}$

3.9 Plasma assisted processes: plasma (ion) carburising 182 
$\begin{array}{lll}3.10 & \text { Plasma (ion) nitriding/nitrocarburising } & \mathbf{1 8 7}\end{array}$

3.11 Implantation processes (nitriding) $\quad \mathbf{1 9 0}$

3.12 Salt bath processes (nitrocarburising) 194

3.13 Laser assisted nitriding $\quad \mathbf{1 9 6}$

3.14 Fluidised bed nitriding $\quad 199$

Acknowledgements $\quad 201$

References $\quad 202$

$\begin{array}{ll}\text { Part Two Improved materials performance } & 207\end{array}$

4 Fatigue resistance of carburized and nitrided steels 209

J. Grosch

4.1 Introduction $\quad \mathbf{2 0 9}$

4.2 The concept of local fatigue resistance $\quad \mathbf{2 1 3}$

4.3 Statistical analysis of fatigue resistance $\mathbf{2 1 6}$

4.4 Fatigue behavior of carburized microstructures $\mathbf{2 1 8}$

4.5 Fatigue behavior of nitrided and nitrocarburized
microstructures

4.6 Conclusion $\quad \mathbf{2 3 6}$

References $\quad 237$

5 Tribological behaviour of thermochemically surface engineered steels

P. A. Dearnley, A. Matthews, A. Leyland

5.1 Introduction 241

5.2 Contact types 241

5.3 Wear mechanisms $\quad \mathbf{2 4 4}$

5.4 Conclusions $\quad \mathbf{2 6 3}$

References $\quad \mathbf{2 6 4}$

6 Corrosion behaviour of nitrided, nitrocarburised and carburised steels

H-J. Spies

6.1 Introduction $\quad \mathbf{2 6 7}$

6.2 Corrosion behaviour of nitrided and nitrocarburised unalloyed and low alloyed steels: introduction

6.3 Nitriding processes and corrosion behaviour

6.4 Structure and composition of compound layers and corrosion behaviour

6.5 Post-oxidation and corrosion behaviour $\quad \mathbf{2 8 0}$

6.6 Passivation of nitride layers $\quad \mathbf{2 8 5}$

6.7 Corrosion behaviour in molten metals $\quad \mathbf{2 8 7}$

6.8 Corrosion behaviour of nitrided, nitrocarburised and carburised stainless steels: introduction 
6.9 Austenitic-ferritic and austenitic steels: corrosion in chloridefree solutions

6.10 Austenitic-ferritic and austenitic steels: corrosion in chloridecontaining solutions

6.11 Ferritic, martensitic and precipitation hardening stainless steels

6.12 Conclusion

References

\section{Part Three Nitriding, nitrocarburizing and carburizing}

$7 \quad$ Nitriding of binary and ternary iron-based alloys

E. J. Mittemeijer

7.1 Introduction

7.2 Strong, intermediate and weak Me-N interaction

7.3 Microstructural development of the compound layer in the presence of alloying elements

7.4 Microstructural development of the diffusion zone in the presence of alloying elements

7.5 Kinetics of diffusion zone growth in the presence of alloying elements

7.6 Conclusion

8 Development of the compound layer during nitriding and nitrocarburising of iron and iron-carbon alloys

M. A. J. Somers

8.1 Introduction

8.2 Compound layer formation during nitriding in a $\mathrm{NH}_{3} / \mathrm{H}_{2}$ gas mixture

8.3 Nitrocarburising in gas

8.4 Compound layer development during salt bath nitrocarburising

8.5 Post-oxidation and phase transformations in the compound layer

8.6 Conclusion

References

9 Austenitic nitriding and nitrocarburizing of steels

R. S. E. Schneider

9.1 Introduction

9.2 Phase stability regions of nitrogen-containing austenite

9.3 Phase transformation of nitrogen-containing austenite and its consequences for the process 
9.4 Phase stability and layer growth during austenitic nitriding and nitrocarburizing

9.5 Properties resulting from austenitic nitriding and nitrocarburizing

9.6 Solution nitriding and its application $\quad 386$ References

10 Classical nitriding of heat treatable steel

L. Barrallier

10.1 Introduction

10.2 Steels suitable for nitriding 393

10.3 Microstructure and hardness improvement 394

$\begin{array}{lll}10.4 & \text { Nitriding-induced stress in steel } & 397\end{array}$

10.5 Nitriding and improved fatigue life of steel $\mathbf{4 0 5}$

References

11 Plasma-assisted nitriding and nitrocarburizing of steel and other ferrous alloys

E. Roliński

11.1 Introduction

11.2 Glow discharge during plasma nitriding: general features $\quad \mathbf{4 1 5}$

11.3 Sputtering during plasma nitriding

11.4 Practical aspects of sputtering and redeposition of the cathode material during plasma nitriding

11.5 Plasma nitriding as a low-nitriding potential process

11.6 Role of carbon-bearing gases and oxygen

11.7 Practical aspects of differences in nitriding mechanism of plasma and gas nitriding processes

11.8 Best applications of plasma nitriding and nitrocarburizing $\quad 441$

11.9 Methods for reducing plasma nitriding limitations $\quad 447$

Acknowledgements

References

12 ZeroFlow gas nitriding of steels

L. Maldzinski, J. Tacikowski

12.1 Introduction

12.2 Improving gas nitriding of steels $\quad \mathbf{4 6 0}$

12.3 Current gas nitriding processes $\quad \mathbf{4 6 0}$

12.4 The principles of ZeroFlow gas nitriding $\quad \mathbf{4 6 1}$

12.5 Thermodynamic aspects of nitriding in atmospheres of $\mathrm{NH}_{3}$ and of two-component $\mathrm{NH}_{3}+\mathrm{H}_{2}$ and $\mathrm{NH}_{3}+\mathrm{NH}_{3}$ diss. mixes

12.6 Kinetic aspects of nitriding in atmospheres of $\mathrm{NH}_{3}$ and of two-component $\mathrm{NH}_{3}+\mathrm{H}_{2}$ and $\mathrm{NH}_{3}+\mathrm{NH}_{3}$ diss. mixes

12.7 Using the ZeroFlow process under industrial conditions $\quad \mathbf{4 6 6}$

12.8 Applications of the ZeroFlow method 
12.9 Conclusion

13 Carburizing of steels

B. Edenhofer, D. Joritz, M. Rink, K. Voges

13.1 Introduction

13.2 Gaseous carburizing

13.3 Low pressure carburizing $\quad \mathbf{5 0 6}$

13.4 Hardening $\mathbf{5 1 4}$

13.5 Tempering and sub-zero treatment $\quad \mathbf{5 2 0}$

13.6 Material properties $\quad \mathbf{5 2 4}$

13.7 Furnace technology $\mathbf{5 3 2}$

13.8 Conclusion $\quad \mathbf{5 4 9}$

References $\quad 549$

Part Four Low temperature carburizing and nitriding

14 Low temperature surface hardening of stainless steel

M. A. J. Somers, T. L. Christiansen

14.1 Introduction

14.2 The origins of low temperature surface engineering of stainless steel

14.3 Fundamental aspects of expanded austenite

References

15 Gaseous processes for low temperature surface hardening of stainless steel

M. A. J. Somers, T. L. Christiansen

15.1 Introduction

581

15.2 Surface hardening of austenitic stainless steel

15.3 Residual stress in expanded austenite

15.4 Prediction of nitrogen diffusion profiles in expanded

15.5 Surface hardening of stainless steel types other than austenite

15.6 Conclusion and future trends

References

16 Plasma-assisted processes for surface hardening of stainless steel

J. P. Lebrun

16.1 Introduction

16.2 Process principles and equipment

16.3 Microstructure evolution 
16.4 Properties of surface hardened steels

627

16.5 Conclusion and future trends

630

References

632

17 Applications of low-temperature surface hardening of stainless steels

J. P. Lebrun

17.1 Introduction

633

17.2 Applications in the nuclear industry

633

17.3 Applications in tubular fittings and fasteners

633

17.4 Miscellaneous applications

638

17.5 Conclusion

642

References

644

647

\section{Part Five Dedicated thermochemical surface engineering} methods

18 Boriding to improve the mechanical properties and corrosion resistance of steels

651

I. E. Campos-Silva, G. A. Rodríguez-Castro

18.1 Introduction $\quad \mathbf{6 5 1}$

$\begin{array}{lll}18.2 & \text { Boriding of steels } & \mathbf{6 5 7}\end{array}$

18.3 Mechanical characterisation of borided steels $\quad \mathbf{6 6 4}$

18.4 Corrosion resistance of steels exposed to boriding $\mathbf{6 9 0}$

18.5 Conclusion $\quad \mathbf{6 9 5}$

$\begin{array}{lr}\text { References } & 697\end{array}$

19 The thermo-reactive deposition and diffusion process for coating steels to improve wear resistance

T. Arai

19.1 Introduction

703

$\begin{array}{ll}19.2 \text { Growth behavior of coatings } & \mathbf{7 0 8}\end{array}$

19.3 High temperature borax bath carbide coating $\mathbf{7 1 6}$

19.4 High temperature fluidizing bed carbide coating $\quad \mathbf{7 2 2}$

$\begin{array}{lll}19.5 & \text { Low temperature salt bath nitride coating } & \mathbf{7 2 5}\end{array}$

19.6 Properties of thermo-reactive deposition (TRD) carbide/nitride coated parts

728

$\begin{array}{lll}19.7 & \text { Applications } & \mathbf{7 3 3}\end{array}$

$\begin{array}{ll}19.8 \text { Conclusion } & \mathbf{7 3 3}\end{array}$

References $\quad 734$ 
20 Sherardizing: corrosion protection of steels by zinc diffusion coatings

F. Natrup, W. Graf

20.1 Introduction

20.2 Pretreatment, surface preparation and processing

20.3 Diffusion heat treatment

739

20.4 Post-treatment, inspection and quality control

746

20.5 Corrosion behavior and mechanical properties

20.6 Applications

20.7 Sources of further information and advice

References

21 Aluminizing of steel to improve high temperature corrosion resistance

V. A. Ravi, T. K. Nguyen, J. C. Nava

21.1 Introduction

21.2 Thermodynamics

21.3 Kinetics

21.4 Aluminizing of austenitic stainless steel - experimental

21.5 Applications

21.6 Conclusion

Acknowledgements

765

References 
This page intentionally left blank 


\section{About the editors}

\section{E. J. Mittemeijer}

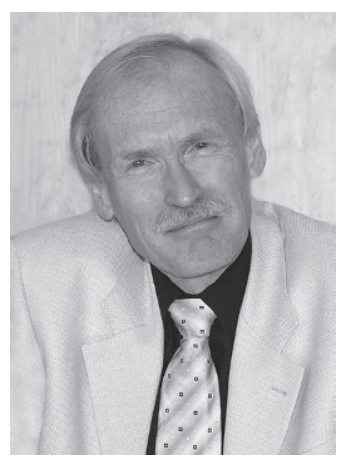

Eric Jan Mittemeijer was born in 1950 in Haarlem, The Netherlands. He studied 'chemical technology', with specialization physical chemistry, at the Delft University of Technology and acquired his 'ingenieur (= Ir.)' degree (comparable to an MSc degree) in 1972 and his Dr. degree in 1978. From 1985 to 1998 he was full Professor of Solid State Chemistry at the Delft University of Technology. Since 1998 he has been Director at the Max Planck Institute for Intelligent Systems (formerly Max Planck Institute for Metals Research) in Stuttgart in conjunction with a full Professorship in Materials Science at the University of Stuttgart. He leads a research department in the field of Phase Transformations. He has (co-)authored more than 600 scientific papers in international scientific journals, wrote a textbook on Materials Science and was editor of several books in his field of science. He has received a number of honours for his scientific work. He can be contacted at: e.j.mittemeijer@is.mpg.de.

\section{A. J. Somers}

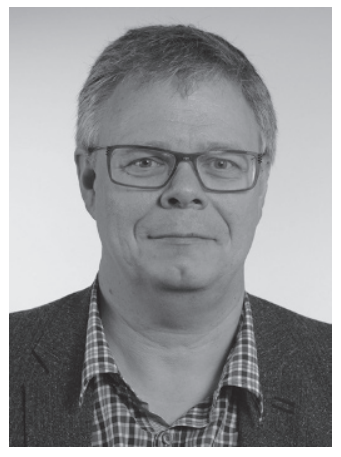

Marcel A. J. Somers was born in 1960 in Vlissingen, The Netherlands. He studied 'physical metallurgy' at the Delft University of Technology (TUD) and acquired his Ir. degree (comparable to an MSc) in 1985 and his Dr.Ir. degree (equivalent to 4 years of research) in 1989. After employments with Philips and at TUD, he became full Professor of Physical Metallurgy in 1997 at the Technical University of Denmark (DTU), where he leads the Section in Materials and Surface Engineering of the Department of Mechanical Engineering. He has (co-)authored over 200 international publications, including several patents. He is the co-founder of two companies in the field of Thermochemical Surface Engineering and has received several honours for his scientific, teaching and innovation activities. He can be contacted at: somers@mek.dtu.dk. 



\section{List of contributors}

T. Arai Consultant, Japan

L. Barrallier Arts et Métiers ParisTech, Paris, France

I. E. Campos-Silva Instituto Politécnico Nacional, Mexico City, México

T. Christiansen Technical University of Denmark (DTU), Kongens Lyngby, Denmark

P. A. Dearnley University of Southampton, Southampton, UK

B. Edenhofer Ipsen International $\mathrm{GmbH}$, Kleve, Germany

W. Graf Impreglon SE, Lüneburg, Germany

J. Grosch Technische Universität Berlin, Berlin, Germany

D. Joritz Ipsen International GmbH, Kleve, Germany

J. Kalucki Nitrex Metal Inc., St-Laurent, QC, Canada

D. Koshel Nitrex Metal Inc., St-Laurent, QC, Canada

J. P. Lebrun Lebrun-Consulting, Bougival, France

A. Leyland University of Sheffield, Sheffield, UK

L. Maldzinski University of Technology Poznań, Poznań, Poland

A. Matthews University of Sheffield, Sheffield, UK

E. J. Mittemeijer Max Planck Institute for Intelligent Systems and Institute for Materials Science, University of Stuttgart, Stuttgart, Germany

F. Natrup SHERART b.v., Helmond, The Netherlands

J. C. Nava California State Polytechnic University Pomona, Pomona, CA, USA

T. K. Nguyen California State Polytechnic University Pomona, Pomona, CA, USA

V. A. Ravi California State Polytechnic University Pomona, Pomona, CA, USA

M. Rink Ipsen International GmbH, Kleve, Germany

G. A. Rodríguez-Castro Instituto Politécnico Nacional, Mexico City, México

E. Roliński Advanced Heat Treat Corp., Monroe, MI, USA 
R. S. E. Schneider University of Applied Sciences Upper Austria - Wels, Wels, Austria

J. T. Slycke Consultant, The Netherlands

M. A. J. Somers Technical University of Denmark (DTU), Kongens Lyngby, Denmark

H-J. Spies Institut für Werkstofftechnik, TU Bergakademie Freiberg, Freiberg, Germany

J. Tacikowski Instytut Mechaniki Precyzyjnej, Warsaw, Poland

K. Voges Ipsen International GmbH, Kleve, Germany

K-M. Winter Process - Electronic GmbH, Heiningen, Germany 


\section{Woodhead Publishing Series in Metals and Surface Engineering}

1 Nickel and chromium plating J. K. Dennis and T. E. Such

2 Microbiologically influenced corrosion handbook

S. Borenstein

3 Surface engineering casebook

Edited by J. S. Burnell-Gray and P. K. Datta

4 Duplex stainless steels

Edited by R. Gunn

5 Engineering coatings

S. Grainger and J. Blunt

6 Developments in marine corrosion

Edited by J. P. Blitz and C. B. Little

7 Fundamental and applied aspects of chemically modified surfaces

J. P. Blitz and C. B. Little

8 Paint and surface coatings

Edited by R. Lambourne and T. A. Strivens

9 Surfacing: Core research from TWI

TWI

10 Recommended values of thermophysical properties for selected commercial alloys

K. C. Mills

11 Corrosion of austenitic stainless steels Edited by H. S. Katal and B. Raj

12 Fundamentals of metallurgy

Edited by S. Seetharaman

13 Energy absorption of structures and materials G. Lu and T.X. Yu

14 The Hatfield memorial lectures: Developments in iron and steel processing Edited by P. R. Beely

15 Laser shock peening

$K$. Ding and L. Ye

16 Structural shear joints

G. T. Hahn, C. A. Rubin and K. A. Iyer

17 Direct strip casting of metals and alloys

M. Ferry

18 Surface coatings for protection against wear

Edited by B. G. Mellor

19 Handbook of gold exploration and evaluation

E. MacDonald

20 The cold spray materials deposition process

Edited by V. K. Champagne

21 The SGTE casebook: Thermodynamics at work: Second Edition

Edited by K. Hack

22 Belt conveying of minerals

E. D. Yardley and L. R. Stace

23 Techniques for corrosion monitoring

Edited by L. Yang 
24 Creep-resistant steels

Edited by F. Abe

25 Developments in high temperature corrosion and protection of materials

Edited by W. Gao

26 Mineral wool: Production and properties

B. Sirok and B. Blagojevic

27 High-performance organic coatings

Edited by A. S. Khana

28 Hydrometallurgy: Principles and applications

T. Havlik

29 Corrosion control in the aerospace industry

Edited by $S$. Benavides

30 Multiaxial notch fatigue

L. Susmel

31 Titanium alloys

W. Sha and S. Malinov

32 Advances in marine antifouling coatings and technologies

Edited by C. Hellio and D. M. Yebra

33 Maraging steels

W. Sha and W. Gao

34 Surface engineering of light alloys

Edited by H. Dong

35 Sintering of advanced materials

Edited by Z. Z. Fang

36 Managing wastes from aluminium smelter plants

B. Mazumber and B. K. Mishra

37 Fundamentals of aluminium metallurgy

Edited by R. Lumley

38 Electroless copper and nickel-phosphorus plating

W. Sha and $X . W u$

39 Thermal barrier coatings

Edited by H. Xu and H. Guo

40 Nanostructured metals and alloys

Edited by S. H. Wang

41 Corrosion of magnesium alloys

Edited by G.L. Song

42 Shape memory and superelastic alloys

Edited by Y. Yamauchi and I. Ohkata

43 Superplasticity and grain boundaries in ultrafine-grained materials

A. L. Zhilyaev and A. I Pshenichnyuk

44 Superplastic forming of advanced metallic materials

Edited by G. Guiliano

45 Nanocoatings and ultra-thin films

Edited by A. S. H. Makhlouf and I. Tiginyanu

46 Stress corrosion cracking

Edited by V. S. Raja and T. Shoji

47 Tribocorrosion of passive metals and coatings Edited by D. Landolt and S. Mischler

48 Metalworking fluids (MWFs) for cutting and grinding Edited by V. P Astakhov and S. Joksch

49 Corrosion protection and control using nanomaterials Edited by V. S. Saji and R. Cook

50 Laser surface modification of alloys for corrosion and erosion resistance Edited by C. T. Kowk 
51 Gaseous hydrogen embrittlement of materials in energy technologies Volume 1: The problem, its characterisation and effects on particular alloy classes

Edited by R. P. Gangloff and B. P. Somerday

52 Gaseous hydrogen embrittlement of materials in energy technologies Volume 2: Mechanisms, modelling and future developments

Edited by R. P. Gangloff and B. P. Somerday

53 Advances in wrought magnesium alloys

Edited by C. Bettles

54 Handbook of metal injection molding

Edited by D. Heaney

55 Microstructure evolution in metal forming processes

Edited by J. Lin and D. Balint

56 Phase transformations in steels Volume 1: Fundamentals and diffusion-controlled transformations

Edited by E. Pereloma and D. V. Edmonds

57 Phase transformations in steels Volume 2: Diffusionless transformations, high strength steels, modelling and advanced analytical techniques

Edited by E. Pereloma and D. V. Edmonds

58 Corrosion prevention of magnesium alloys

Edited by G. L. Song

59 Fundamentals of magnesium alloy metallurgy

Edited by M. Pekguleryuz, K. Kainer and A. Kaya

60 Advances in powder metallurgy

Edited by I. Chang

61 Rare earth-based corrosion inhibitors

Edited by $M$. Forsyth and B. Hinton

62 Thermochemical surface engineering of steels

Edited by E. J. Mittemeijer and M. A. J. Somers

63 Underground pipeline corrosion: Detection, analysis and prevention

Edited by M. Orazem

64 Handbook of smart coatings for materials protection

Edited by A. S. H. Makhlouf 



\section{Introduction}

Corrosion, wear and fatigue are among the most important mechanisms that lead to materials degradation, which, eventually, leads to failure of components. The annual loss by material degradation owing to these mechanisms alone is assessed at 7-8\% of a nation's gross national product (GNP), at least in the western world. Thus there is a great potential for saving resources, provided that the fundamentals of material behaviour, and thus its performance including degradation, are understood, in order to define on that basis strategies to improve the intrinsic properties of materials. This requires acquisition of scientific understanding rather than the accumulation of empirical data.

Corrosion, wear and fatigue involve chemical and/or mechanical interaction of the material component considered with loads imposed by the environment. Hence, materials performance and service life rely in many cases to a high degree on the properties of a material component in its surface region. Accordingly, engineering the intrinsic properties of the surface region to improve materials performance suggests itself, thus giving birth to the discipline of Surface Engineering. Obviously the number of conceivable surface engineering process variants to tailor any possible combination of structural or functional properties is endless. Indeed, the number of surface engineering processes in use at present is overwhelming.

From the very beginning of surface engineering, thermochemical processes have played a dominant role for realizing structural properties. The adjective 'thermochemical' should be interpreted as indicating a deliberate change of the chemical composition of the material at elevated temperature. This is accomplished by a thermally activated chemical reaction of the material's surface with one (or more) component(s) supplied by an appropriate environment as a gas, a plasma, a salt bath or a (powder) pack. Upon dissolution of the externally supplied component(s) into the surface, thermally activated (inter)diffusion, possibly, but not necessarily, accompanied by phase transformations, leads to a desired modification of the microstructure. The best known and most widely applied processes are case hardening ${ }^{1}$ by carburizing and nitriding of steel components.

We have deliberately restricted this book to thermochemical surface engineering methods, rather than attempting to provide an overview of all possible surface engineering methods, which would have made this book either too bulky or superficial.

1 'Case hardening' is a name usually reserved for carburizing methods, but in fact it is a generic name; it expresses that a hard 'case' (the surface region) is produced on an unaltered, relatively soft 'core'. Because, on the one hand, this interpretation limits severely the range of properties possibly and deliberately modified by surface engineering, and, on the other hand, identifying case hardening with carburizing (of steels) is an illogical narrowing of the field covered, we prefer to avoid using 'case hardening' for 'carburizing', although this is done frequently in the literature. 
Materials are usually not used in a state of equilibrium. This holds in particular for materials in components subjected to a thermochemical surface engineering treatment, where the composition and the associated microstructure in the surface region of the component are (very) different from those in the bulk. Therefore, understanding the properties of materials of graded composition and microstructure, requires knowledge of the thermodynamics, i.e. the state of equilibrium strived for, and the kinetics of the surface engineering processes applied. On the one hand and unfortunately, such knowledge is only available to a limited extent at a fundamental level. On the other hand, a wealth of phenomenological data is offered by the literature and forms the basis for many surface engineering methods applied in (commercial) practice. Yet, we have tried with this book also to provide an overview of the scientific knowledge available on thermochemical surface engineering. It appears that such fundamental knowledge is largely restricted to gaseous treatments, because gaseous media, in contrast to salts, packs and plasmas, can be controlled such that the prevailing chemical potentials of the (active) species are known and can be measured and controlled precisely. For the same reason the kinetics of the surface reactions are practically only known comprehensively for the metal-gas reactions.

Against the above background, in the first chapter of this book, we have tried to present an overview of what is known about the thermodynamics of gaseous media used for carburizing and nitriding processes and their variants, and about the kinetics of the associated metal-gas reactions. The data provided and the calculation methods presented offer a unique review of the state of the art not available in any other literature source known to us. In particular, we have integrated in the text original and important data hitherto only available in papers written in German, thereby making possible their use worldwide.

Chapter 2 is devoted to a general description of the kinetics of (a) transport of species originating from the outer atmosphere through the solid, and (b) the possible reaction of this species with components in the solid, leading to phase transformation, with the product phase(s) emerging as (a) separate layer(s) at the surface or as dispersed particles in the substrate matrix.

Chapter 3 is devoted to the general principles of the process technology of the (usual) thermochemical surface engineering methods. As will be clear to the reader of this chapter, the strictly science-based approach of Chapters 1 and 2 is substituted by an overview of also more experience-based knowledge of great importance for successful thermochemical surface engineering.

The basis for understanding current thermochemical surface engineering processes is provided by these first three chapters.

The chapters in Part Two are devoted to the optimization of certain properties by dedicated thermochemical surface engineering: the fatigue resistance (Chapter 4), the wear resistance (Chapter 5) and the corrosion resistance (Chapter 6).

As indicated above, thermochemical surface engineering is dominated by nitriding/nitrocarburizing (Chapters 7-12) and carburizing (Chapter 13) and their variants. In these chapters (Part Three) fundamental aspects of the effects on the generated microstructure (especially Chapters 7, 8 and 13) as well as the process 
technological aspects (Chapters 9, 11 and 13) are dealt with. Specific examples of practical application are provided in Chapter 12.

A development of recent years is 'low temperature surface hardening of stainless steels', sometimes indicated by the unfortunate name 'S-phase surface engineering', which is the topic of Part Four. The purpose is the uptake of an unusually large amount of interstitial nitrogen and/or carbon in the surface adjacent region of a stainless steel, nickel or cobalt alloy. After a historical review of the development and the fundamental aspects of this method (Chapter 14), its variants for application using gaseous media (Chapter 15) and plasma media (Chapter 16) are presented and discussed. The final chapter of this part provides specific examples of practical application (Chapter 17).

The final part of this book (Part Five) presents a number of less often, but still frequently applied and thus important thermochemical surface engineering methods for dedicated applications: boriding (Chapter 18), thermoreactive deposition and diffusion (Chapter 19), sherardizing (Chapter 20) and aluminizing (Chapter 21).

This book, as follows from the description above, is intended to provide an overview of the current knowledge on thermochemical surface engineering. Therefore we are particularly grateful to the many authors who contributed enthusiastically to this project and enriched it with their knowledge.

This book was long in the making and thus we are grateful for the patience of those of the contributing authors who had to wait a long time to see their manuscript in print. The team at Woodhead Publishing, Francis Dodds and Emily Cole, helped us with many small but important details, not least by their understanding for and willingness to accept shifting deadlines. Last but not least, we are very much obliged to our spouses, Marion and Sussi, for their infinite support; without their acceptance of numerous private hours being consumed by us, a project like this would have been impossible.

It is then hoped that this book will be used by many and will stimulate young people to contribute to future developments in the field.

Eric J. Mittemeijer

Max Planck Institute for Intelligent Systems, Institute for Materials Science, University of Stuttgart,

Stuttgart, Germany

Marcel A. J. Somers

Technical University of Denmark, Kongens Lyngby, Denmark 